\title{
WORLD FEDERATION OF TRADE UNIONS (WFTU)
}

Origin and History. The WFTU was founded on a worldwide basis in 1945 at the international trade union conferences held in London and Paris, with the participation of all the trade union centres in the countries of the anti-Hitler coalition. The aim was to reunite the world trade union movement at the end of the Second World War. The acute political differences among affiliates, especially the east-west confrontation in Europe on ideological lines, led to a split. A number of affiliated organizations withdrew in 1949 and established the ICFTU. The WFTU now draws its membership from the industrially developing countries like India, Vietnam and other Asian countries, Brazil, Peru, Cuba and other Latin American countries, Syria, Lebanon, Kuwait and other Arab countries, and it has affiliates and associates in more than 20 European countries. It has close relations with the International Confederation of Arab Trade Unions, the Organization of African Trade Union Unity as well as the All-China Federation of Trade Unions, all of which participated at its Congress in New Delhi, India in 2000. Its Trade Unions Internationals (TUIs) have affiliates in Russia, the Czech Republic, Poland and other East European countries, Portugal, France, Spain, Japan and other OECD countries.

The headquarters of the TUIs are situated in Helsinki, New Delhi, Budapest, Mexico, Paris and Moscow. The WFTU and its TUIs have $130 \mathrm{~m}$. members, organized in 92 affiliated or associated national federations and six Trade Unions Internationals, in 130 countries. It has regional offices in Athens, New Delhi, Havana, Dakar, Damascus and Moscow and Permanent Representatives accredited to the UN in New York, Geneva, Paris and Rome.

Headquarters: POB 80, Posta 411, 14200 Prague 4, Czech Republic.

Website: http://www.wftu.cz

e-mail:wftu@login.cz

President: K. L. Mahendra (India).

General Secretary: Aleksander Zharikov (Russia).

Publications. Flashes From the Trade Unions (fortnightly, published in English, French, Spanish and Arabic), reports of Congresses, etc.

\section{WORLD WIDE FUND FOR NATURE (WWF)}

Origin. WWF was officially formed and registered as a charity on 11 Sept. 1961. The first National Appeal was launched in the United Kingdom on 23 Nov. 1961, shortly followed by the United States and Switzerland.

Organization. WWF is the world's largest and most experienced independent conservation organization with over $4.7 \mathrm{~m}$. supporters and a global network of 27 National Organizations, five Associates and 24 Programme Offices.

The National Organizations carry out conservation activities in their own countries and contribute technical expertise and funding to WWF's international conservation programme. The Programme Offices implement WWF's fieldwork, advise national and local governments, and raise public understanding of conservation issues.

Mission. WWF has as its mission preserving genetic, species and ecosystem diversity; ensuring that the use of renewable natural resources is sustainable now and in the longer term, for the benefit of all life on Earth; promoting actions to reduce to a minimum pollution and the wasteful exploitation and consumption of resources and energy. WWF's ultimate goal is to stop, and eventually reverse, the accelerating degradation of our planet's natural environment, and to help build a future in which humans live in harmony with nature.

Address: Avenue du Mont-Blanc, $\mathrm{CH}-1196$ Gland, Switzerland.

Website: http://www.panda.org

Director General: Dr Claude Martin (Switzerland).

President Emeritus: HRH The Prince Philip, Duke of Edinburgh.

President: Chief Emeka Anyaoku (Nigeria). 